\title{
Biomarkers in the diagnosis of lysosomal storage disorders: proteins, lipids, and inhibodies
}

\author{
Johannes M. F. G. Aerts • Wouter W. Kallemeijn • Wouter Wegdam • \\ Maria Joao Ferraz • Marielle J. van Breemen • Nick Dekker • Gertjan Kramer • \\ Ben J. Poorthuis • Johanna E. M. Groener • Josanne Cox-Brinkman • \\ Saskia M. Rombach • Carla E. M. Hollak • Gabor E. Linthorst • Martin D. Witte • \\ Henrik Gold • Gijs A. van der Marel • Herman S. Overkleeft • Rolf G. Boot
}

Received: 21 December 2010 /Revised: 21 January 2011 /Accepted: 17 February 2011 / Published online: 29 March 2011

(C) The Author(s) 2011. This article is published with open access at Springerlink.com

\begin{abstract}
A biomarker is an analyte indicating the presence of a biological process linked to the clinical manifestations and outcome of a particular disease. In the case of lysosomal storage disorders (LSDs), primary and secondary accumulating metabolites or proteins specifically secreted by storage cells are good candidates for biomarkers. Clinical applications of biomarkers are found in improved diagnosis, monitoring disease progression, and assessing therapeutic correction. These are illustrated by reviewing the discovery and use of biomarkers for Gaucher disease and Fabry disease. In addition, recently developed chemical tools allowing specific visualization of enzymatically active lysosomal glucocerebrosidase are described. Such probes, coined inhibodies, offer entirely new possibilities for more sophisticated molecular diagnosis, enzyme replacement therapy monitoring, and fundamental research.
\end{abstract}

Communicated by: Ed Wraith

Competing interests: None.

Presented at: the Annual Symposium of the SSIEM, Istanbul, Turkey, 31 August - 3 September 2010.

J. M. F. G. Aerts $(\triangle) \cdot$ W. W. Kallemeijn • W. Wegdam •

M. Joao Ferraz • M. J. van Breemen • N. Dekker · G. Kramer •

B. J. Poorthuis · J. E. M. Groener · J. Cox-Brinkman ·

S. M. Rombach - C. E. M. Hollak - G. E. Linthorst - R. G. Boot

Sphinx-Amsterdam Lysosome Center, Departments of Medical

Biochemistry and Internal Medicine, Academic Medical Centre,

University of Amsterdam,

Meibergdreef 15,

1105 AZ Amsterdam, The Netherlands

e-mail: j.m.aerts@amc.uva.nl

M. D. Witte $\cdot$ H. Gold $\cdot$ G. A. van der Marel $\cdot$ H. S. Overkleeft Department of Bio-organic Synthesis,

Leiden Institute for Chemistry, Leiden University,

Leiden, The Netherlands

\section{Introduction}

Lysosomal storage disorders Continuous recycling of their macromolecular constituents is essential for the functional integrity of long-lived cells. This molecular rejuvenation depends not only on permanent biosynthesis but also on permanent degradation of macromolecules. To handle the potential risky turnover of macromolecular constituents, hydrolytic processes are largely contained in specific acid subcellular compartments named lysosomes (lysein=cleave, somos $=$ body) by their discoverer Christian de Duve (de Duve et al. 1955). Henri G. Hers ( 1963)first realized that deficiency of a particular lysosomal enzyme (acid alphaglucosidase) was the cause of glycogen storage disease type 2, also called Pompe disease. This discovery led to the concept of lysosomal storage disorders (LSDs), of which more than 70 have now been described. The birth prevalence of individual LSDs is thought to vary between 1 in 20,000100,000 live births. Collectively, the entire group of LSDs affects at least 1 in 5,000-10,000 live births (Meikle et al. 1999; Poorthuis et al. 1999). Lysosomal storage disorders may present with a broad range of phenotypes, with variable age of onset, symptom severity, and degree of central nervous system (CNS) involvement. Many LSDs manifest as a spectrum encompassing more severe (infantile) and milder (juvenile and adult) forms. Infantile forms often display CNS involvement and are therefore called neuronopathic, in contrast to the non-neuronopathic subtypes. For instance, in Gaucher disease (beta-glucocerebrosidase deficiency), the most severe phenotype presents with severe neurological involvement and death soon after birth, whereas at the other end of the phenotypic spectrum, patients are found in whom diagnosis is made in late adulthood based on minimal visceral symptoms (Aerts et al. 1993). 
LSD therapy In recent decades, remarkable progress has been made in LSD treatment. The general principle of treatment is lowering the excessive amount of stored substrate, which can be achieved either by enhanced substrate degradation or by reduced substrate production. Enhanced substrate degradation can be achieved by two different approaches. First, hematopoietic cell transplantation (HCT) with cells from unaffected individuals can deliver the missing enzyme to the deficient cells of the recipient. HCT has been used in an attempt to treat numerous different LSDs, but to now, it has only been proven effective in a small number of disorders (see Boelens et al. 2010 for a review). The second approach to enhance substrate degradation is by direct intravenous delivery of the deficient enzyme, which may partly restore the deficient enzymatic capacity. This concept, named enzyme replacement therapy (ERT), is based on the principle that lysosomal proteins can reach the subcellular lysosomes via endocytosis mediated by lectins on the plasma membrane, such as the mannose 6-phosphate receptor and the mannose receptor. Gaucher disease was the first LSD for which this type of treatment became available. The first enzyme preparation used to treat nonneuronopathic type 1 Gaucher disease consisted of placenta-derived glucocerebrosidase with modified, mannose-terminated glycans, allowing more selective uptake by tissue macrophages that are the prominent storage cells in Gaucher disease (Barton et al. 1991; Hollak et al. 1995; Bijsterbosch et al. 1996). This product was later replaced by recombinant enzyme (Cerezyme; Genzyme), which proved to be very successful in treating the visceral and bone complications of Gaucher disease (de Fost et al. 2007; Pastores et al. 2004). Very recently, an alternative recombinant enzyme preparation (Velaglucerase alfa; Shire), produced in human cells, was registered for ERT of type 1 Gaucher disease (Aerts et al. 2010). An exciting new development forms the production of recombinant glucocerebrosidase by Protalix in plant cells (Aviezer et al. 2009). The plant-derived recombinant enzyme preparation (named taliglucerase alfa) is hoped to be comparatively effective and increase the choice between treatment modalities (Aviezer et al. 2009). A third and more recent development, also aimed at enhancing substrate degradation, is the use of small compounds that act as chaperones for mutant enzymes (see Smid et al. 2010 for a recent review). Whereas the above-mentioned therapeutic approaches are based on stimulating the breakdown of the accumulated substrate, an alternative strategy is aimed at decreasing the amount of substrate by partially inhibiting its synthesis. This approach, requiring well-tolerated and specific enzymatic inhibitors, is named substrate reduction therapy (SRT). The most well-known and studied compound that acts by SRT is a glucosylceramide synthase inhibitor, N-butyldeoxynojirimycin (miglustat), which catalyses the first step in the glucosylceramide biosynthetic pathway (Platt et al. 2001; Aerts et al. 2006). Miglustat has been extensively studied for its use in Gaucher disease type 1 and is registered for patients with mild to moderate Gaucher disease type 1 who are unable or unwilling to receive ERT (Cox et al. 2000, 2003). The long-term experience with miglustat treatment in type 1 Gaucher patients is satisfactory (Elstein et al. 2004; Heitner et al. 2002; Elstein et al. 2007), and anecdotal reports suggest that combination SRT and ERT may be beneficial for some type 3 neuronopathic Gaucher patients (Cox-Brinkman et al. 2008). The development of an alternative small-molecule compound for oral substrate reduction therapy, eliglustat tartrate, by Genzyme is also exciting (McEachern et al. 2007). The compound seems to be safe and well tolerated (Lukina et al. 2010b), and a 2-year follow-up of a phase II trial indicated major improvements in hematological, visceral, and skeletal manifestations in adult patients with type 1 Gaucher disease on a par with ERT (Lukina et al. 2010a). Moreover, as ERT is not able to prevent or treat neurological abnormalities in severely affected patients because the enzymes are unable to pass the blood-brain barrier (Schiffmann et al. 1997), such compounds could provide a much needed treatment option for these patients. Another approach being studied for treating CNS disease is direct introduction of the deficient enzyme into the brain (Lonser et al. 2005; Begley 2004; Dickson et al. 2007). Alternative strategies to deliver modified enzymes from the circulation across the bloodbrain barrier are also being investigated (Begley 2004; Urayama et al. 2007). The preclinical therapeutic approach remains gene therapy. Numerous hurdles, such as transient expression of transgenes, immunological responses, and tumor induction, have so far discouraged the clinical application of gene therapy. However, as in recent years enormous progress has been made with respect to efficacy and safety of viral vectors, with encouraging results in application in animal models for LSDs, there is still great hope for application of gene therapy (Fig. 1).

Monitoring disease manifestations and therapeutic intervention Accurate quantitative monitoring of disease manifestations as well as of the therapeutic efficacy of any type of treatment is crucial for clinical management of patients with LSDs. Disease onset and progression can be monitored by clinical, radiological, and laboratory assessments. Clinical assessments obviously differ among the various LSDs, as illustrated below for Gaucher disease and Fabry disease. In practice, clinical therapeutic efficacy is often difficult to assess, as organ involvement can sometimes not be quantitatively assessed and is highly variable among patients. Moreover, some symptoms have an irreversible nature, such as advanced renal failure in Fabry disease or 
Fig. 1 Gaucher cell accumulating the glycosphingolipid glucosylceramide and specifically secreting the biomarker chitotriosidase that can be detected in plasma. Example of corrections in plasma chitotriosidase in Gaucher disease patients receiving enzyme replacement therapy

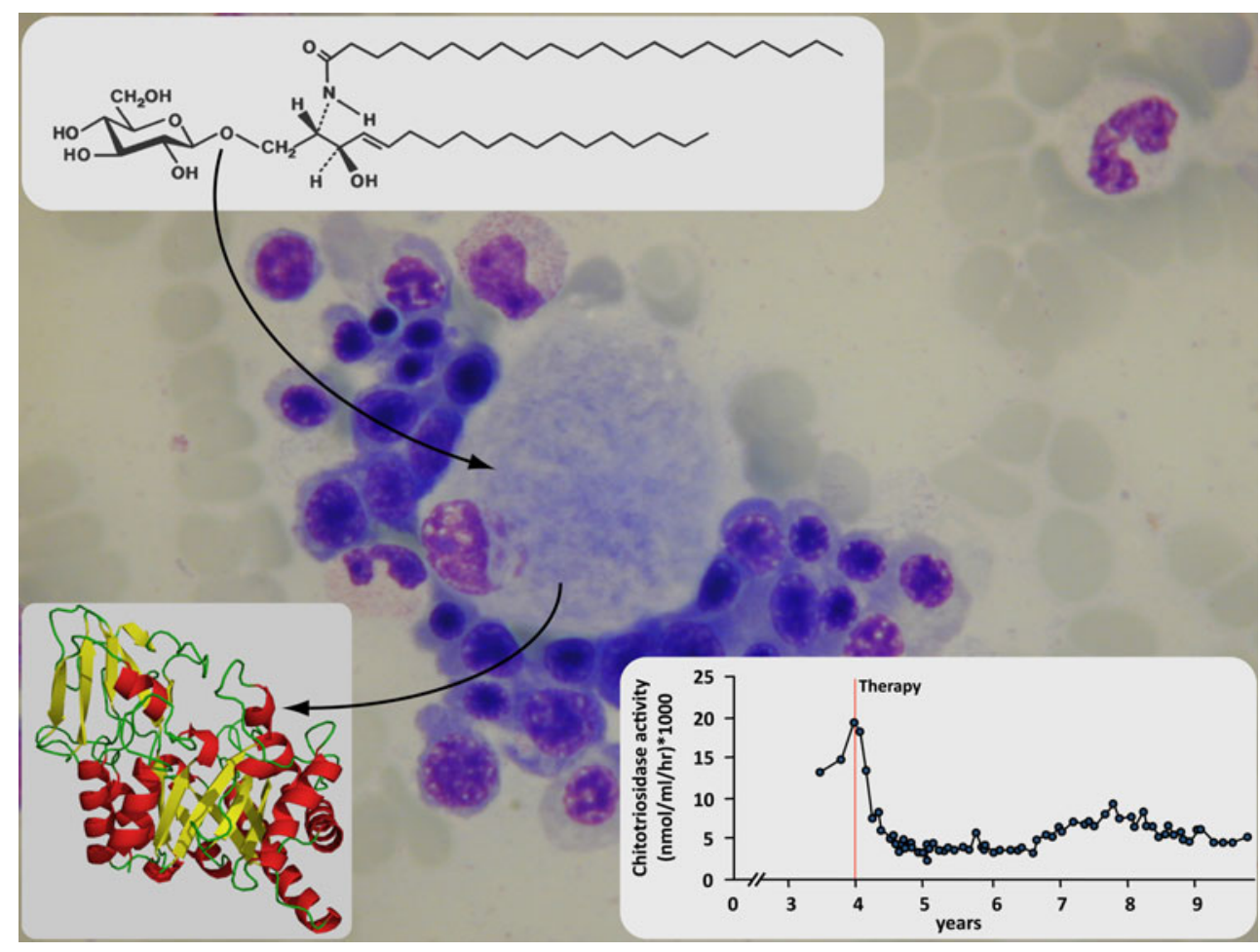

bone infarctions in Gaucher disease. Increasingly, diseasespecific biochemical abnormalities are used to monitor disease progression and treatment efficacy for LSDs.

\section{Biomarkers}

Biomarkers are generally defined as chemical entities, ranging from simple metabolites to complex proteins, which indicate the presence of a biological process linked to the clinical manifestations and outcome of a particular disease. The value of biomarkers is appreciated by most clinicians and biomedical researchers as well as the authorities. In a recent report on biomarkers, the European Medicines Agency (EMA) states that: "Biomarkers play an increasingly important role in the development of new drugs. It is expected that they will help increase the rate of success of new developments and to expedite the development of drugs. Also, biomarkers are key in the shift away from the 'one size fits all' to 'the right drug at the right dose in the right patient' approach. Hence, biomarkers play an important role for scientists and industry in drug development and for regulators in the approval process" (EMA 2006). To date, biomarkers are already widely used in the clinical management of some conditions. An obvious example is the measurement of blood glucose and/or glycosylated hemoglobin in diabetic individuals. Candidate biomarkers for LSDs can be divided into two categories. The first group consists of molecules that accumulate in tissues and body fluids directly due to the enzymatic defect.
The second group includes molecules produced by storage cells in a specific LSD and can be measured either in plasma, urine, or cerebrospinal fluid (CSF). Identifying and applying such biomarkers for Gaucher disease and Fabry disease are discussed, and their use is illustrated.

\section{Gaucher disease}

A prominent LSD is Gaucher disease (Beutler et al. 2001; Aerts et al. 2003). Brady and co-workers first showed that the primary defect in Gaucher disease is a marked deficiency in activity of the lysosomal enzyme glucocerebrosidase (Brady et al. 1966). Deficiencies in glucocerebrosidase result in accumulation of its lipid substrate glucosylceramide in the lysosomal compartment of macrophages throughout the body. Different phenotypes (types 1, 2 , and 3) are generally recognized and are differentiated on the basis of the presence or absence of neurological symptoms. Whether a strict division in three different phenotypes is still valid has been the subject of debate, as there are an increasing number of reports on neurological manifestations in patients with type 1 Gaucher disease. However, the neurological signs and symptoms in type 1 Gaucher disease are of a totally different kind from and, in the majority of cases, of much less severity than, the signs and symptoms associated with types 2 and 3 disease (Biegstraaten et al. 2008). It has also become apparent that complete deficiencies in glucocerebrosidase activity occur, resulting in major skin permeability abnormalities with lethal consequences either prenatally or shortly after birth 
(Sidransky 2004). The most common Gaucher phenotype is non-neuronopathic type 1 manifestation, with a highly variable age of onset and severity. Even spontaneous disease regression has been observed in some relatively mildly affected type 1 Gaucher patients (Boomsma et al. 2010). Characteristic symptoms include splenomegaly with anemia and thrombocytopenia, hepatomegaly, and bone disease. Anemia may contribute to chronic fatigue. Thrombocytopenia and prolonged clotting times can lead to an increased bleeding tendency. Atypical bone pain, pathological fractures, avascular necrosis, and extremely painful bone crises may also have a great impact on quality of life. Gammopathies and metabolic abnormalities such as insulin resistance and lipoprotein abnormalities are encountered in type 1 Gaucher patients (Langeveld et al. 2007, 2008b; Wennekes et al. 2009; de Fost et al. 2009, 2008). Type 1 Gaucher disease is relatively common in all ethnic groups. It is prevalent among Ashkenazi Jews, with a carrier frequency as high as about 1 in 15 and an incidence of about 1 in 1,000 . The most common mutation in the glucocerebrosidase gene of Caucasians, including Ashkenazi Jews, encodes the amino acid substitution N370S. The heteroallelic presence of the N370S mutation is always associated with a nonneuronopathic course (Ohashi et al. 1991; van Weely et al. 1993b). Some, but not all, homozygotes for the N370S mutation develop significant clinical symptoms (Beutler et al. 2001; Aerts et al. 2003). Twin studies and the poor predictive power of genotype-phenotype investigations in Gaucher disease have clearly pointed out that epigenetic factors also play a key role in Gaucher disease manifestation (Biegstraaten et al. 2010).

The diagnosis of Gaucher disease can be confirmed by demonstration of reduced glucocerebrosidase activity in lysates of various cell types and even urine samples using the fluorogenic substrate 4-methylumbelliferyl betaglucoside (Aerts et al. 1985, 1986b). Fluorescent analogues of the lipid glucosylceramide can be exploited to measure glucocerebrosidase activity in cultured cells (Van Weely et al. 1991). Highly specific monoclonal antibodies against human glucocerebrosidase have been produced and can be used in purification of the protein, Western blot analysis, and microscopy techniques (Aerts et al. 1986a, 1988). Although glucocerebrosidase is present in the lysosomes of all cell types, patients with type 1 Gaucher disease only store glucosylceramide in macrophages. It is believed that the storage material stems from the breakdown of exogenous lipids derived from the turnover of blood cells. The glucosylceramide-loaded macrophages of Gaucher patients show a characteristic morphology with a wrinkled-paper appearance of their cytoplasm, which contains lysosomal inclusion bodies; these cells are referred to as Gaucher cells. In recent decades, it has become apparent that Gaucher cells are not inert containers of storage material but are viable, chronically activated macrophages that contribute to the diverse clinical manifestations of Gaucher disease. These mature, activated macrophages are surrounded by newly formed, highly inflammatory macrophages in tissue lesions of patients with Gaucher disease (Boven et al. 2004). Consistent with these observations, patients with Gaucher disease show increased plasma levels of several proinflammatory and anti-inflammatory cytokines, chemokines, and hydrolases (Aerts and Hollak 1997; Aerts et al. 2008a; Hollak et al. 1997b; Michelakakis et al. 1996; Hollak et al. 1997a; Møller et al. 2004). Factors released by Gaucher cells and surrounding macrophages are thought to play a crucial role in the development of common abnormalities in Gaucher patients, such as osteopenia, activation of coagulation, hypermetabolism, gammopathies, multiple myeloma, and hypolipoproteinemias (Aerts and Hollak 1997).

Biomarkers of Gaucher cells Given the prominent role of Gaucher cells in the pathophysiology of the disorder, considerable attention has been focused on identifying plasma markers for such macrophages. Abnormalities in levels of tartrate-resistant acid phosphatase (TRAP), angiotensin-converting enzyme (ACE), hexosaminidase, and lysozyme in serum samples from Gaucher patients had been documented for some time (Aerts and Hollak 1997). More recently, increased plasma levels of various cathepsins, including cathepsin $\mathrm{K}$, were reported in patients with Gaucher disease (Moran et al. 2000; van Breemen et al. 2008). All of these proteins are known to be produced by macrophages; however, none of them appears to be a specific marker for the pathological Gaucher cells, and their levels in the serum of symptomatic patients with Gaucher disease may overlap with those observed in healthy individuals. Their use as biomarkers for Gaucher cells is, therefore, restricted. The need for a very sensitive and specific marker for Gaucher cells prompted a search for such a parameter. This search led to the discovery of a striking abnormality in the serum of symptomatic patients with Gaucher disease.

Chitotriosidase Serum from such individuals showed a 1,000-fold increased capacity to degrade the fluorogenic substrate 4-methylumbelliferyl chitotrioside (Hollak et al. 1994). The corresponding enzyme had hitherto not been described and was named chitotriosidase. The chitotriosidase protein was subsequently purified and its complementary DNA (cDNA) cloned (Renkema et al. 1995; Boot et al. 1995). Chitotriosidase was found to be the human analogue of chitinases from lower organisms (Rao et al. 2005). The enzyme hydrolyzes chitin, the natural polymer of beta1,4 N-acetylglucosamine, is a member of the large chitinase protein family created by gene duplications (Bussink et al. 
2007). Besides chitotriosidase, the chitinase protein family includes one other active enzyme-AMCase (Boot et al. 2001) - and several inactive lectins (Bussink et al. 2007; Renkema et al. 1998). Chitotriosidase is specifically expressed by phagocytes in humans, including macrophages and neutrophils (Renkema et al. 1997; van Eijk et al. 2005). The enzyme is similar in structure to nonvertebrate chitinases (Fusetti et al. 2002; Rao et al. 2003). It has been shown to exert a fungistatic action of degradation of the protective chitin layer at the hyphal tip of fungi (van Eijk et al. 2005). In situ hybridization and histochemistry of bone marrow aspirates and sections of spleens from patients with Gaucher disease revealed that chitotriosidase is massively produced by storage cells. This is also supported by the close linear relationship between chitotriosidase and glucosylceramide levels in different spleen sections from patients with Gaucher disease (Bussink et al. 2006). In a culture model of Gaucher cells, chitotriosidase accounts for almost $10 \%$ of the total secreted protein. In sharp contrast, common tissue macrophages do not produce chitotriosidase. These observations help us to understand the very specific, gross elevation of chitotriosidase levels in the blood of patients with Gaucher disease. A relationship between the total body burden of storage cells in patients with Gaucher disease and their plasma chitotriosidase levels has been noted. The plasma chitotriosidase level does not reflect any one particular clinical symptom of Gaucher disease, suggesting, rather, that it reflects the sum of secreted enzyme by Gaucher cells in various body locations. Plasma chitotriosidase levels can be determined by monitoring hydrolysis of the fluorogenic substrate 4-methylumbelliferyl-chitobioside. However, the ability of chitotriosidase to transglycosylate as well as hydrolyze this substrate complicates the enzyme assay (Aguilera et al. 2003). Special care has to be taken to ensure that the enzyme activity is truly proportional to the amount of chitotriosidase protein. A far more convenient, sensitive, and accurate detection is feasible by measuring the activity of chitotriosidase toward the recently designed fluorogenic substrate 4-methylumbelliferyl-deoxy-chitotrioside (Aguilera et al. 2003; Schoonhoven et al. 2007). Interpretation of plasma chitotriosidase levels is intrinsically complicated by the common occurrence of a particular 24-base-pair duplication in the chitotriosidase gene, preventing the formation of chitotriosidase protein (Aguilera et al. 1998). In most ethnic groups, about one in every three individuals carries this abnormality, and about one in every 20 individuals, including patients with Gaucher disease, is homozygous for this trait (Aguilera et al. 1998). It has been established that carriers of the 24-bp duplication show half the amount of plasma chitotriosidase detected in individuals with the wildtype chitotriosidase genotype (Aguilera et al. 1998). It is therefore common to correct plasma chitotriosidase by a factor of two when examining patients with Gaucher disease who are carriers of the 24-bp duplication. Other polymorphisms have also been detected, of which the G102S substitution is the most frequent (allele frequency of about 0.25 ). This polymorphism leads to an enzyme with a slightly impaired catalytic activity toward the 4-methylumbelliferylchitotrioside substrate compared with wild type. However, G102S enzyme activity is normal when using 4methylumbelliferyl-deoxy-chitobioside as substrate (Bussink et al. 2009). It should be mentioned that increased plasma chitotriosidase activity is not unique for Gaucher patients. Plasma chitotriosidase activity is increased, albeit much more modestly, in several lysosomal and nonlysosomal diseases, such as sarcoidosis, visceral Leishmaniasis, leprosy, arthritis, multiple sclerosis, thalassemia, chronic obstructive pulmonary disease (COPD), malaria, and atherosclerosis (Hollak et al. 1994; Guo et al. 1995; Brinkman et al. 2005; vom Dahl et al. 1999; Vedder et al. 2006a; Boot et al. 2010; Iyer et al. 2009; Boven et al. 2006; Boot et al. 1999; Labadaridis et al. 1998).

PARC/CCL18 The high frequency of chitotriosidase deficiency prompted us to search for an alternative marker of Gaucher cells. Using surface-enhanced laser distortion/ ionization time of flight (SELDI-TOF) mass spectrometric analyses, we discovered massive overproduction and secretion by Gaucher cells of the pulmonary and activation-regulated chemokine (PARC/CCL18), of which the messenger RNA (mRNA) was previously observed to be up-regulated in the spleen of a patient with Gaucher disease (Moran et al. 2000; Boot et al. 2004). This plasma PARC/CCL18 cannot be reliably quantified using SELDITOF, but reliable quantification is obtained by ELISA (van Breemen et al. 2006). Plasma PARC/CCL18 levels are 10to 40-fold elevated in symptomatic Gaucher patients (Boot et al. 2004; Deegan et al. 2005). Due to its basic nature and small molecular mass, PARC/CCL18 levels in urine are proportional to those in the circulation. Therefore, urinary PARC/CCL18 excretion offers insight into the body burden of Gaucher cells (Boot et al. 2006). Measurement of plasma PARC/CCL18 has been found to yield an excellent additional tool to monitor changes in body burden of Gaucher cells. It is particularly useful for evaluating patients that are chitotriosidase deficient (Cox et al. 2008).

MIP-1 $\alpha$ and MIP-1 $\beta$ Van Breemen and co-workers reported markedly elevated levels of the chemokines macrophage inflammatory protein (MIP)- $1 \alpha$ and MIP- $1 \beta$ in plasma of symptomatic Gaucher patients (van Breemen et al. 2007). Interestingly, with immunohistochemistry, these proteins were found to be produced by surrounding inflammatory spleen macrophages and not by mature Gaucher cells (van Breemen et al. 2007). The different 
cellular source is also reflected in the observation that plasma chitotriosidase and PARC/CCL18, both stemming from Gaucher cells, respond comparably to ERT. However, corrections in plasma MIP- $1 \alpha$ and MIP- $1 \beta$ following ERT are not proportional to those found with the true Gauchercell biomarkers (van Breemen et al. 2009). A relationship was observed between plasma MIP-1 $\beta$ and skeletal disease: stable high plasma MIP-1 $\beta$ levels despite prolonged ERT were found to correlate with ongoing skeletal disease (van Breemen et al. 2007). Clearly, rigorous analysis of a large cohort of Gaucher patients is required to establish the value of plasma MIP-1 $\beta$ (or MIP- $1 \alpha$ ) as biomarker, especially its value as prognostic marker for skeletal response to therapy.

Clinical applications of Gaucher-cell biomarkers Plasma chitotriosidase measurement is commonly employed as a first screen in the diagnosis of Gaucher disease. Increasing plasma levels seem to reflect gradual accumulation of storage cells in the patient's body. In an attempt to assess the utility of plasma chitotriosidase activity measurement as a biomarker for treatment efficacy, Hollak and co-workers investigated the relationship between enzyme activity and clinical parameters (Hollak et al. 2001). In patients with high clinical severity scores, chitotriosidase levels were usually $>20,000 \mathrm{nmol} / \mathrm{ml} / \mathrm{h}$ and always $>15,000 \mathrm{nmol} / \mathrm{ml} / \mathrm{h}$, whereas patients with less severe disease tended to have lower values. During enzyme supplementation therapy, the mean decrease in 12 months was $32 \%$ (range $0-82 \%$ ), and $78 \%$ of patients had a decrease of $>15 \%$. In six patients with a decrease in chitotriosidase activity of $<15 \%$, the clinical response to treatment was inferior to that of other patients, with less reduction in organomegaly in four and bone problems in two. In addition, chitotriosidase response was related to disease severity; less reduction in plasma activity was seen in more severely affected individuals. On the basis of this investigation, it has been proposed that in patients in whom the initiation of treatment is questionable based solely on clinical parameters, a chitotriosidase activity $>15,000 \mathrm{nmol} / \mathrm{ml} / \mathrm{h}$ may serve as an indicator of a high Gaucher-cell burden and an indication for treatment initiation (Hollak et al. 2001). A reduction in chitotriosidase activity of $<15 \%$ after 12 months of treatment, in combination with an insufficient response of at least one clinical parameter, should be a reason to consider dose increase. Furthermore, a sustained increase in chitotriosidase at any point during treatment should alert the physician to the possibility of clinical deterioration and the need for dose adjustment. A recent retrospective analysis by Deegan and co-workers confirmed the value of the use of plasma chitotriosidase in Gaucher disease management and presented evidence for comparable use of PARC/CCL18 (Deegan et al. 2005). In conclusion, next to radiological monitoring of the bone marrow and skeleton (Maas et al. 2002, 2003; Poll et al. 2002), measurement of plasma levels of chitotriosidase and/or PARC/CCL18 offers valuable information for clinical management of type 1 Gaucher patients.

Lipid biomarkers of Gaucher disease Increased plasma concentrations of glucosylceramide, the primary storage lipid, have been documented for Gaucher patients (Groener et al. 2008; Erikson et al. 2006). Plasma glucosylceramide is not used as a biomarker, as its increase generally is not very pronounced. Moreover, the exact relation between circulating glucosylceramide and storage cells in tissues is far from clear. Interestingly, besides glucosylceramide, the ganglioside GM3 is also elevated in Gaucher plasma samples (Ghauharali-van der Vlugt et al. 2007). Increases of GM3 have also been noted in spleens of Gaucher patients. This secondary elevation of GM3 may not be without consequences. Elevated glycosphingolipids such as GM3 are thought to cause insulin resistance (Aerts et al. 2007). Indeed, a recent study revealed that Gaucher patients are insulin resistant without overt hyperglycemia (Langeveld et al. 2008a; Langeveld and Aerts 2009). Other secondary lipid abnormalities in Gaucher patients have been noted by thorough investigations by Fuller and coworkers, such as elevated levels of phosphatidylglycerol (Hein et al. 2007; Meikle et al. 2008). The diagnostic value and possible physiological consequences warrant further investigations.

Discovery of additional protein biomarkers for Gaucher disease Ongoing attention is paid to the detection of useful protein biomarkers for Gaucher disease by a thorough survey of protein composition of bodily fluids, or cell and tissue specimens of symptomatic Gaucher patients. The latter approach has more recently become feasible due to the availability of mass spectrometric techniques that allow accurate analysis of proteins, even in complex mixtures such as plasma and urine samples. Recently, label-free liquid chromatography mass spectrometry (LC-MS) quantification methods have been developed. These methods are typically based on determining peak-area ratios of the same peptides between different conditions. Using a label-free LC-MS approach (so-called LC-MS ${ }^{\mathrm{E}}$ ), a series of plasma specimens from type 1 Gaucher patients prior to and after therapy were studied (Vissers et al. 2007). Marked therapyinduced differences were noted in the Gaucher disease protein plasma profile. Comparison with the normal plasma profile revealed that many protein abnormalities in symptomatic patients were at least partially corrected by successful therapy (Vissers et al. 2007). LC-MS ${ }^{\mathrm{E}}$ is used by us to study the proteome of laser-capture-dissected Gaucher cells from spleens of Gaucher patients. 
Fabry disease

Fabry disease is an X-linked LSD resulting from deficient activity of the lysosomal hydrolase $\alpha$-galactosidase A (EC 3.2.1.22) (Desnick and Ioannou 2001; Brady et al. 1967). In male patients with severe forms of Fabry disease, there is usually severely reduced or complete lack of enzymatic activity. Relatively high residual enzyme activity is often noted in patients with a milder variant of Fabry disease with predominantly cardiac abnormalities, whereas there is little or no kidney dysfunction and no painful acroparesthesia (Desnick and Ioannou 2001). However, many female heterozygotes also display symptoms despite considerable amounts of circulating residual enzyme that varies due to random $\mathrm{X}$ inactivation. This sharply contrasts with the general lack of symptoms among carriers of another Xlinked lysosomal hydrolase deficiency, Hunter disease. Deficiency of $\alpha$-galactosidase A results in accumulation of its glycosphingolipid substrates in lysosomes of endothelial, perithelial, and smooth-muscle cells of the vascular system, as well as renal epithelial cells, myocardial cells, and cells of the autonomic nervous system. The accumulating glycosphingolipids contain terminal $\alpha$-galactosyl moieties, such as globotriaosylceramide (Gb3; also known as ceramide trihexoside: $\mathrm{CTH})$; galabiosylceramide $(\mathrm{Gb} 2)$; and, to a lesser extent, blood group $\mathrm{B}, \mathrm{B} 1$, and $\mathrm{P}_{1}$ antigens (Desnick and Ioannou 2001). Two different recombinant $\alpha$ galactosidase A preparations are in use for treating Fabry disease (Schiffmann et al. 2001; Eng et al. 2001). One enzyme is produced by Chinese hamster ovary $(\mathrm{CHO})$ cells with classic recombinant technology (agalsidase $\beta$, Fabrazyme), and the other enzyme is produced by cultured human skin fibroblasts with an activated promoter of the $\alpha$ gal A gene (agalsidase $\alpha$, Replagal). Both recombinant enzymes are quite comparable in properties and differ only slightly in glycan composition (Blom et al. 2003). The two enzyme preparations have independently been examined in clinical investigations and are both registered in Europe for treating Fabry patients. Although both enzyme therapies were found to result in the desired clearance of globotriaosylceramide from the endothelium, the clinical effects are not as robust as anticipated. In some patients, stabilization of renal function and improvement in cardiac hypertrophy occurs upon therapy, but a considerable number experiences progressive complications (Vedder et al. 2007a).

Numerous screening studies for Fabry disease have been undertaken and are ongoing (Linthorst et al. 2010). Some investigations rely on detection of abnormalities in the GLA gene. A serious complication in this connection is the difficulty of distinguishing whether some of the commonly encountered abnormalities in the GLA gene are truly disease-causing mutations or polymorphisms that are not obligate disease causing (Froissart et al. 2003). Other screening procedures are based on the demonstration of reduced enzymatic activity in blood cells, plasma, or dried blood spots. An associated limitation of such methods is the inability to reliably detect female carriers and some atypically affected male hemizygotes. As an alternative screening method, it is contemplated by Hopwood and colleagues to use quantification of $\alpha$-Gal A protein with specific antibodies in analogy to screening for other lysosomal enzymopathies (Tan et al. 2008).

Fabry biomarkers Following the successful biomarker discovery for Gaucher disease, attempts have been made to identify comparable metabolite and protein biomarkers for Fabry disease.

Lack of prominent plasma protein abnormalities In symptomatic Fabry patients, abnormalities are encountered that point to a low-grade inflammatory disorder (Schiffmann 2009). Indeed, increased circulating levels of C-reactive protein (CRP) and the hydrolases myeloperoxidase, metalloproteinase 9, and chitotriosidase, have been reported for symptomatic Fabry hemizygotes (Vedder et al. 2006a; Kaneski et al. 2006; Shah et al. 2007). The abnormalities in the hydrolases, all produced by phagocytes, are not very striking and certainly not specific for Fabry disease. As inflammation is not thought to be a major component of Fabry disease, the value of the above-mentioned hydrolases as biomarkers seems limited. Monitoring corrections induced by therapy in the levels of abnormal hydrolases may, however, be informative. For example, clear reductions were noted in elevated chitotriosidase in male Fabry patients during enzyme therapy and relapses following the induction of neutralizing antibodies against the therapeutic enzyme (Vedder et al. 2006a). The prevalent concept is that Fabry disease is a systemic vasculopathy due to Gb3 storage in endothelial cells. Considerable attention has therefore been focused on identifying plasma protein abnormalities reflecting endothelial activation. Known plasma proteins reflecting endothelial activation have been considered as candidate biomarkers for Fabry disease. This has been further stimulated by various reports demonstrating disturbed vascular circulation and a prothrombotic state in Fabry disease (Moore et al. 2007a). Laboratory investigations that have been performed to assess determinants of coagulation or activation of the endothelium in Fabry patients are not always in accordance. In a very recent, thorough study conducted with a large cohort of Fabry patients in the Academic Medical Center in Amsterdam, only minimal abnormalities in indicators of coagulation, fibrinolysis, and platelet and endothelial activation were detected (Vedder et al. 2009). Next to targeted analysis of plasma proteins already known to reflect endothelial activation, the search for protein biomarkers of Fabry 
disease has been extended to analysis of the entire plasma proteome. Moore and co-workers were the first to elegantly investigate plasma of children with Fabry disease prior to and after ERT using tryptic digestion of plasma protein and differentially labelling peptides with stable isotopes, such that consistent mass differences were introduced into selected amino acid residues (Moore et al. 2007b). The LC-MS analysis showed only modest therapy-induced changes in a few proteins. Most importantly, it stimulated the investigators to further analyze $\alpha-2$-antiplasmin concentrations in Fabry patients using citrate-based plasma specimens and a chromogenic method. The mean level of $\alpha$-2-antiplasmin in 34 Fabry patients aged $10-55$ years was $85 \%$ vs. normal laboratory mean of 105 ; range $82-123 \%$. A systematic proteomics analysis of blood specimens from Fabry patients conducted at the Academic Medical Center in Amsterdam has not led to the discovery of prominent abnormalities in plasma proteins in symptomatic Fabry patients (Aerts and co-workers, manuscript in preparation).

Lipid abnormalities as potential Fabry biomarkers For a long time, the primary accumulating globoside $\mathrm{Gb} 3$ has been considered as a surrogate marker for Fabry disease. Reduction of $\mathrm{Gb} 3$ in tissue biopsies has actually served as the criterion for the registration of agalsidase beta. The globoside $\mathrm{Gb} 3$ is not only elevated inside storage cells but is also present in abnormally high concentrations in bodily fluids, such as plasma and urine. It is very well documented that in symptomatic Fabry hemizygotes both plasma and urinary Gb3 are increased (Desnick and Ioannou 2001). Intriguingly, in female carriers of Fabry disease, urinary $\mathrm{Gb} 3$ is generally increased, but plasma Gb3 levels tend to be in the normal range (Vedder et al. 2007c). Various methods have meanwhile been developed for detecting Gb3. Mass-spectrometry-based and high-performance liquid chromatography (HPLC)-based procedures have become available, allowing accurate quantification of the globoside (Mills et al. 2004; Fauler et al. 2005; Fuller et al. 2005; Auray-Blais et al. 2007; Groener et al. 2007). Demonstration of increased $\mathrm{Gb} 3$, either in plasma or urine, is of great value for diagnostic purposes, particularly for putative Fabry females carrying a GLA mutation with unclear consequences. It has been reported that urinary Gb3 levels correlate with the predicted severity of GLA mutations (Auray-Blais et al. 2008).

Globotriaosylceramide (Gb3) The value of plasma or urinary $\mathrm{Gb} 3$ as biomarker to monitor progression of Fabry disease is questionable. In several investigations, plasma or urinary $\mathrm{Gb} 3$ has been found to poorly reflect Fabry disease manifestation and therapeutic outcome (Vedder et al. 2007c; Young et al. 2005; Whitfield et al. 2005; Bekri et al. 2006). For example, many male Fabry patients lacking endogenous $\alpha$-galactosidase A develop neutralizing antibodies during ERT (Linthorst et al. 2004). The occurrence of such antibodies is accompanied by a relapse in elevated plasma $\mathrm{Gb} 3$, but the clinical significance of this remains unclear (Vedder et al. 2008). The poor predictive value of plasma or urinary Gb3 levels for Fabry disease manifestation is not entirely surprising. Prominent $\mathrm{Gb} 3$ accumulation has been noted in placental tissue of a Fabry hemizygote (Popli et al. 1990; Vedder et al. 2006b), a finding illustrating that onset of clinical complications occurs only after several years of lipid deposition. Gb3 accumulation apparently occurs in hemizygotes at or even before birth, long before any clinical symptoms are prominent. The same discrepancy between early storage of $\mathrm{Gb} 3$ and clinical symptoms is also noted in Fabry mice generated by disruption of the GLA gene (Ohshima et al. 1997). Plasma $\mathrm{Gb} 3$ concentrations in some presymptomatic boys have been found to exceed those in symptomatic adult hemizygotes (Vedder et al. 2007c), The absence of infantile manifestations in Fabry patients completely lacking $\alpha$ galactosidase A activity also indicates that $\mathrm{Gb} 3$ accumulation does not cause immediately, and maybe even not directly, signs of disease. An investigation by Barbey and co-workers provided evidence for the presence of an unidentified substance in plasma of symptomatic Fabry disease patients that stimulates proliferation of vascular smooth-muscle cells and cardiomyocytes in vitro (Barbey et al. 2006a). It is conceivable that this substance is a causative factor in the development of left ventricular hypertrophy and increased intima media thickness in Fabry patients (Boutouyrie et al. 2002; Barbey et al. 2006b; Kalliokoski et al. 2006; Vedder et al. 2007b; Rombach et al. 2010b).

Globotriaosylsphingosine (lysoGb3) The puzzling findings prompted us to re-examine $\mathrm{Gb} 3$ and its metabolites in Fabry patients (Aerts et al. 2008b). During this investigation, it was discovered that plasma of Fabry patients contains markedly increased concentrations of deacylated globotriaosylceramide, globotriaosylsphingosine (here abbreviated as lysoGb3). The relative increase in plasma concentrations of the cationic amphiphilic lysoGb3 spectacularly exceeds that of $\mathrm{Gb} 3$ by more than an order of magnitude. High nanomolar lysoGb3 concentrations occur in plasma samples from symptomatic male Fabry patients. Also in the case of symptomatic female Fabry patients, clearly increased levels of lysoGb3 were detected, whereas concomitantly, $\mathrm{Gb} 3$ concentrations were in the high-normal range (Aerts et al. 2008b). Thus, measurement of plasma lysoGb3 seems to offer a very useful diagnostic tool, particularly in the case of female Fabry patients. Meanwhile, the findings for lysoGb3 in Fabry disease have been confirmed by independent investigations (Togawa et al. 
2010b; Auray-Blais et al. 2010; Togawa et al. 2010a). Using a more sensitive mass spectrometrical detection, Auray-Blais and co-workers demonstrated the presence of elevated lysoGb3 in urine samples of Fabry patients (Auray-Blais et al. 2010). The relationship between plasma lysoGb3 concentrations and Fabry disease manifestations has been investigated (Rombach et al. 2010a). It is clear that in Fabry hemizygotes, both in humans and mice, plasma lysoGb3 is already increased at birth and consequently does not correlate strictly with symptoms (Aerts et al. 2008b; Rombach et al. 2010b). In the case of female hemizygotes, lysoGb3 is low at birth and increases gradually with age. Some degree of correlation of plasma lysoGb3 levels and disease manifestation seems to exist for female hemizygotes. Preliminary data indicate that high plasma lysoGb3 correlates with increased risk for cerebrovascular disease in males (Rombach et al. 2010b). Of interest, life-time exposure to plasma lysoGb3 is found to correlate with disease severity in male as well as female patients (Rombach et al. 2010b). These observations suggest, but certainly do not prove, that lysoGb3 plays a direct role in the pathogenesis of Fabry disease. A role as pathogenic factor for lysoGb3 is suggested by the elegant studies of Ortiz and co-workers (Sanchez-Niño et al. 2010). They demonstrated that exposure of cultured glomerular podocytes to lysoGb3 increased the expression of tumor growth factor (TGF)-beta-1, extracellular matrix proteins (fibronectin and type IV collagen), and CD74. It was concluded from these findings that lysoGb3 may have a role in glomerular injury in Fabry disease by promoting the release of secondary mediators of glomerular injury common to diabetic nephropathy (Sanchez-Niño et al. 2010). It has already been found that lysoGb3 at concentrations occurring in plasma of symptomatic Fabry patients is able to induce proliferation of smooth-muscle cells in vitro, possibly explaining the increased intima media thickness in Fabry patients (Boutouyrie et al. 2002; Barbey et al. 2006b; Kalliokoski et al. 2006; Vedder et al. 2007b; Rombach et al. 2010a). The effect of ERT on plasma lysoGb3 has recently been reported (van Breemen et al. 2011). Reassuringly, therapy was found to be followed by reduced plasma lysoGb3 levels.

\section{Inhibodies: new, versatile tools for diagnosis, monitoring therapeutic enzyme targeting and fundamental research}

A major limitation so far in evaluating LSDs has been the lack of a technology that allows selective labeling of active lysosomal hydrolases in vitro and in vivo. The availability of such a method would allow more advanced diagnostic tests and more sophisticated monitoring of tissue targeting of therapeutic proteins, and would boost fundamental research on lysosomal hydrolases. Recently we conceived such a method for the lysosomal glucocerebrosidase based on activity-based covalent labeling of the enzyme's nucleophile, glutamate 340 , with fluorescent probes. The catalytic mechanism of glucocerebrosidase, a retaining beta-glucosidase, has been elucidated in detail (Liou and Grabowski 2009; Rempel and Withers 2008). We employed the fact that conduritol B-epoxide and cyclophellitol are potent suicide inhibitors of glucocerebrosidase (van Es et al. 1994; Atsumi et al. 1993). By coupling a fluorescent boron-dipyrromethene (BODIPY) moiety via a triazole linker to cyclophellitol, extremely potent fluorescent suicide inhibitors for glucocerebrosidase were generated (Witte et al. 2010). The probes are amphiphilic and easily penetrate cells, allowing in vitro and in vivo labeling of glucocerebrosidase in cells and whole organisms. The term inhibody is coined for these types of probes, as they act as suicide inhibitors and allow direct visualization of originally active enzyme molecules with comparable methods as used for specific antibodies. The detection power of the developed inhibodies for glucocerebrosidase is amazing: as little as a few attomoles of enzyme can be visualized on slab gels by fluorescence scanning. The specificity of glucocerebrosidase labeling with the inhibody probes is also extraordinary high, even when tissues are analyzed (Atsumi et al. 1993). It has been demonstrated that the probes can be used for diagnostic purposes, allowing visualization of active glucocerebrosidase in very few cultured skin fibroblasts. The probes can also be employed for fluorescence-activated cell-sorting analysis, fluorescence microscopy, and pulse-chase experiments (Atsumi et al. 1993). It is envisioned that comparable specific probes can be designed for other retaining lysosomal glycosidases by adaptations in the sugar configuration.

An interesting potential application for inhibodies is to be found in subtle labeling of therapeutic recombinant protein and monitoring its tissue distribution following intravenous administration. The use of a near-infrared fluorophore to enable visualization of therapeutic glucocerebrosidase in individual patients is appealing. A similar approach was recently reported using a radio-tagged suicide inhibitor, allowing visualization of administered labeled glucocerebrosidase in mice using positron emission tomography (Phenix et al. 2010).

Another area of application for the fluorescent inhibody probes is laid in fundamental research. It now becomes feasible to obtain information about the exact tissue distribution of enzymatically active glucocerebrosidase. Such information may render new insights into Gaucher disease and help our understanding of why carriership for the disorder constitutes a risk factor for parkinsonism (Goker-Alpan et al. 2008). Glucocerebrosidase remains in 
many aspects an enigmatic enzyme. It is transported to lysosomes independently of the mannose-6-phophate receptor system (Aerts et al. 1988; Rijnboutt et al. 1991a; Rijnboutt et al. 1991b).. The membrane protein LIMP2 has been shown to act as sorting receptor in certain cell types, such as fibroblasts (Reczek et al. 2007). Other cell types, including blood cells, apparently can employ an alternative sorting receptor (Balreira et al. 2008). Analysis of LIMP2deficient mice and humans with the available inhibody probes for glucocerebrosidase may be of great value in this connection. A next challenge is designing comparable probes that recognize and label several beta-glucosidases. Besides glucocerebrosidase, humans contain other betaglucosidases, such as GBA2 (van Weely et al. 1993a; Boot et al. 2007; Yildiz et al. 2006; Dekker et al. 2010) and GBA3 [163] that might play a role in the pathogenesis of Gaucher disease.

In summary, the search for biomarkers of Gaucher disease have been extraordinary productive. Next to elevations in circulating glucosylceramide and gangliosides such as GM3 in Gaucher patients, striking abnormalities in plasma concentrations of some proteins have been identified. For example, increases in chitotriosidase up to $10,000-$ fold above normal have been identified in some Gaucher patients. For some of these proteins, i.e., chitotriosidase and PARC/CCL18, it has been demonstrated that they stem from storage cells. The circulating levels of these proteins offer insight into the total burden of storage cells in Gaucher patients. Regular monitoring of chitotriosidase, or PARC/CCL18 in chitotriosidase-deficient individuals, with sensitive assays is widely applied in Gaucher clinics and assists in clinical decision making.

The outcome of investigations on protein biomarkers for Fabry disease has been comparatively disappointing. Accurate methods have been developed to quantify the primary storage lipid $\mathrm{Gb} 3$ in plasma and urine specimens. However, it is generally felt that measurement of plasma and urinary Gb3 is only useful for diagnostic purposes and offers no sensitive tool to monitor Fabry disease progression. An exciting new development is the discovery of elevated lysoGb3 in Fabry patients. Laboratory findings suggest that lysoGb3 may even play a direct pathogenic role. Systematic and solid investigations with large cohorts of Fabry patients are necessary to reveal the true value of lysoGb3 as biomarker. In any case, the demonstration of increased plasma lysoGb3 in female heterozygotes offers an important additional diagnostic tool.

The availability of fluorescent probes, so-called inhibodies, which allow selective labeling ultrasensitive detection of glucocerebrosidase offers new opportunities for diagnosis of the disorder. In addition, the probes may be employed in the future in monitoring tissue distribution of recombinant therapeutic protein in individual Gaucher patients. Finally, inhibo- dies may boost fundamental research on glucocerebrosidase and the pathogenesis of Gaucher disease and parkinsonism.

\section{Biomarkers, biochemical abnormalities, and surrogate markers of disease}

In the case of lysosomal storage diseases, biochemical abnormalities can be identified in blood and/or urine samples as described above for Gaucher and Fabry disease. Not all of these abnormalities should be called biomarkers. Such terminology should be restricted to abnormalities that are disease specific and are in the context of disease manifestation, for example, circulating protein or metabolite markers stemming from storage cells. Generally, these biomarkers reflect not one particular symptom but rather the total body burden of storage cells. Thus, such biomarkers are not true surrogate markers of disease that accurately reflect a particular symptom in one organ. Although some of the available biomarkers, such as chitotriosidase, may assist in clinical management, further studies analyzing the correlation between long-term biomarker responses and objective clinical outcome parameters following therapeutic interventions are still warranted.

Acknowledgments The authors thank their colleagues in the clinical departments and research laboratories in the Academic Medical Center focussing on lysosomal storage disorders. The continuous support by the Netherlands Fabry Patient Society and VKS is gratefully acknowledged.

Open Access This article is distributed under the terms of the Creative Commons Attribution Noncommercial License which permits any noncommercial use, distribution, and reproduction in any medium, provided the original author(s) and source are credited.

\section{References}

Aerts JM, Hollak CE (1997) Plasma and metabolic abnormalities in Gaucher's disease. Baillières Clin Haematol 10:691-709

Aerts JM, Donker-Koopman WE, van der Vliet MK, Jonsson LM, Ginns EI, Murray GJ, Barranger JA, Tager JM, Schram AW (1985) The occurrence of two immunologically distinguishable betaglucocerebrosidases in human spleen. Eur J Biochem 150(3):565-574

Aerts JM, Donker-Koopman WE, Murray GJ, Barranger JA, Tager JM, Schram AW (1986a) A procedure for the rapid purification in high yield of human glucocerebrosidase using immunoaffinity chromatography with monoclonal antibodies. Anal Biochem 154:655-663

Aerts JM, Donker-Koopman WE, Koot M, Barranger JA, Tager JM, Schram AW (1986b) Deficient activity of glucocerebrosidase in urine from patients with type 1 Gaucher disease. Clin Chim Acta 158:155-163

Aerts JM, Schram AW, Strijland A, van Weely S, Jonsson LM, Tager JM, Sorrell SH, Ginns EI, Barranger JA, Murray GJ (1988) Glucocerebrosidase, a lysosomal enzyme that does not undergo oligosaccharide phosphorylation. Biochim Biophys Acta 964:303-308

Aerts JM, Van Weely S, Boot R, Hollak CE, Tager JM (1993) Pathogenesis of lysosomal storage disorders as illustrated by Gaucher disease. J Inherit Metab Dis 16:288-291 
Aerts JM, Hollak C, Boot R, Groener A (2003) Biochemistry of glycosphingolipid storage disorders: implications for therapeutic intervention. Philos Trans R Soc Lond B Biol Sci 358:905-914

Aerts JM, Hollak CE, Boot RG, Groener JE, Maas M (2006) Substrate reduction therapy of glycosphingolipid storage disorders. J Inherit Metab Dis 29:449-456

Aerts JM, Ottenhoff R, Powlson AS, Grefhorst A, van Eijk M, Dubbelhuis PF, Aten J, Kuipers F, Serlie MJ, Wennekes T, Sethi JK, O'Rahilly S, Overkleeft HS (2007) Pharmacological inhibition of glucosylceramide synthase enhances insulin sensitivity. Diabetes 56:1341-1349

Aerts JM, van Breemen MJ, Bussink AP, Ghauharali K, Sprenger R, Boot RG, Groener JE, Hollak CE, Maas M, Smit S, Hoefsloot HC, Smilde AK, Vissers JP, de Jong S, Speijer D, de Koster CG (2008a) Biomarkers for lysosomal storage disorders: identification and application as exemplified by chitotriosidase in Gaucher disease. Acta Paediatr Suppl 97:7-14

Aerts JM, Groener JE, Kuiper S, Donker-Koopman WE, Strijland A, Ottenhoff R, van Roomen C, Mirzaian M, Wijburg FA, Linthorst GE, Vedder AC, Rombach SM, Cox-Brinkman J, Somerharju P, Boot RG, Hollak CE, Brady RO, Poorthuis BJ (2008b) Elevated globotriaosylsphingosine is a hallmark of Fabry disease. Proc Natl Acad Sci USA 105:2812-2817

Aerts JM, Yasothan U, Kirkpatrick P (2010) Velaglucerase alfa. Nat Rev Drug Discov 9:837-838

Aguilera B, Ghauharali-van der Vlugt K, Helmond MT, Out JM, Donker-Koopman WE, Groener JE, Boot RG, Renkema GH, Verhoek M, Strijland A, Bliek J, de Meulemeester TM, Mannens MM, Aerts JM (1998) The human chitotriosidase gene. Nature of inherited enzyme deficiency. J Biol Chem 273:25680-25685

Aguilera B, Ghauharali-van der Vlugt K, Helmond MT, Out JM, Donker-Koopman WE, Groener JE, Boot RG, Renkema GH, van der Marel GA, van Boom JH, Overkleeft HS, Aerts JM et al (2003) Transglycosidase activity of chitotriosidase: improved enzymatic assay for the human macrophage chitinase. J Biol Chem 278:40911-40916

Atsumi S, Nosaka C, Iinuma H, Umezawa K (1993) Accumulation of tissue glucosylsphingosine in Gaucher-like mouse induced by the glucosylceramidase inhibitor cyclophellitol. Arch Biochem Biophys 304:302-304

Auray-Blais C, Cyr D, Mills K, Giguère R, Drouin R (2007) Development of a filter paper method potentially applicable to mass and high-risk urinary screenings for Fabry disease. J Inherit Metab Dis 30:106

Auray-Blais C, Cyr D, Ntwari A, West ML, Cox-Brinkman J, Bichet DG, Germain DP, Laframboise R, Melançon SB, Stockley T, Clarke JT, Drouin R (2008) Urinary globotriaosylceramide excretion correlates with the genotype in children and adults with Fabry disease. Mol Genet Metab 93:331-340

Auray-Blais C, Ntwari A, Clarke JT, Warnock DG, Oliveira JP, Young SP, Millington DS, Bichet DG, Sirrs S, West ML, Casey R, Hwu WL, Keutzer JM, Zhang XK, Gagnon R (2010) How well does urinary lyso-Gb3 function as a biomarker in Fabry disease? Clin Chim Acta 411:1906-1914

Aviezer D, Brill-Almon E, Shaaltiel Y, Hashmueli S, Bartfeld D, Mizrachi S, Liberman Y, Freeman A, Zimran A, Galun E (2009) A plant-derived recombinant human glucocerebrosidase enzymea preclinical and phase I investigation. PLoS ONE 4:e4792

Balreira A, Gaspar P, Caiola D, Chaves J, Beirão I, Lima JL, Azevedo JE, Miranda MC (2008) A nonsense mutation in the LIMP-2 gene associated with progressive myoclonic epilepsy and nephrotic syndrome. Hum Mol Genet 17:2238-2243

Barbey F, Brakch N, Linhart A, Rosenblatt-Velin N, Jeanrenaud X, Qanadli S, Steinmann B, Burnier M, Palecek T, Bultas J, Hayoz D (2006a) Cardiac and vascular hypertrophy in Fabry disease: evidence for a new mechanism independent of blood pressure and glycosphingolipid deposition. Arterioscler Thromb Vasc Biol 26:839-844

Barbey F, Brakch N, Linhart A, Jeanrenaud X, Palecek T, Bultas J, Burnier M, Hayoz D (2006b) Increased carotid intima-media thickness in the absence of atherosclerotic plaques in an adult population with Fabry disease. Acta Paediatr Suppl 95:63-68

Barton NW, Brady RO, Dambrosia JM, Di Bisceglie AM, Doppelt SH, Hill SC, Mankin HJ, Murray GJ, Parker RI, Argoff CE et al (1991) Replacement therapy for inherited enzyme deficiencymacrophage-targeted glucocerebrosidase for Gaucher's disease. N Engl J Med 324:1464-1470

Begley DJ (2004) Delivery of therapeutic agents to the central nervous system: the problems and the possibilities. Pharmacol Ther 104:29-45

Bekri S, Lidove O, Jaussaud R, Knebelmann B, Barbey F (2006) The role of ceramide trihexoside (globotriaosylceramide) in the diagnosis and follow-up of the efficacy of treatment of Fabry disease: a review of the literature. Cardiovasc Hematol Agents Med Chem 4(4):289-297

Beutler E, Grabowski G (2001) Gaucher disease. In: Scriver CR, Beaudet AL, Sly WS, Valle D (eds) The metabolic and molecular bases of inherited diseases. McGraw-Hill, New York, pp 36353668

Biegstraaten M, van Schaik IN, Aerts JM, Hollak CE (2008) 'Nonneuronopathic' Gaucher disease reconsidered. Prevalence of neurological manifestations in a Dutch cohort of type I Gaucher disease patients and a systematic review of the literature. J Inherit Metab Dis 31:337-349

Biegstraaten M, van Schaik IN, Aerts JM, Langeveld M, Mannens MM, Bour LJ, Sidransky E, Tayebi N, Fitzgibbon E, Hollak CE (2010) A monozygotic twin pair with highly discordant Gaucher phenotypes. Blood Cells Mol Dis 46:39-41

Bijsterbosch MK, Donker W, van de Bilt H, van Weely S, van Berkel TJ, Aerts JM (1996) Quantitative analysis of the targeting of mannose-terminal glucocerebrosidase. Predominant uptake by liver endothelial cells. Eur J Biochem 237:344-349

Blom D, Speijer D, Linthorst GE, Donker-Koopman WG, Strijland A, Aerts JM (2003) Recombinant enzyme therapy for Fabry disease: absence of editing of human alpha-galactosidase A mRNA. Am J Hum Genet 72:23-31

Boelens JJ, Prasad VK, Tolar J, Wynn RF, Peters C (2010) Current international perspectives on hematopoietic stem cell transplantation for inherited metabolic disorders. Pediatr Clin North Am $57: 123-145$

Boomsma JM, van Dussen L, Wiersma MG, Groener JE, Aerts JM, Maas M, Hollak CE (2010) Spontaneous regression of disease manifestations can occur in type 1 Gaucher disease; results of a retrospective cohort study. Blood Cells Mol Dis 44:181-739

Boot RG, Renkema GH, Strijland A, Van Zonneveld AJ, Aerts JM (1995) Cloning of a cDNA encoding chitotriosidase, a human chitinase produced by macrophages. J Biol Chem 270:2625226256

Boot RG, van Achterberg TA, van Aken BE, Renkema GH, Jacobs MJ, Aerts JM, de Vries CJ (1999) Strong induction of members of the chitinase family of proteins in atherosclerosis: chitotriosidase and human cartilage gp-39 expressed in lesion macrophages. Arterioscler Thromb Vasc Biol 19:687-694

Boot RG, Blommaart EF, Swart E, Ghauharali-van der Vlugt K, Bijl N, Moe C, Place A, Aerts JM (2001) Identification of a novel acidic mammalian chitinase distinct from chitotriosidase. J Biol Chem 276:6770-6778

Boot RG, Verhoek M, De Fost M, Hollak CE, Maas M, Bleijlevens B, van Breemen MJ, van Meurs M, Boven LA, Laman JD, Moran MT, Cox TM, Aerts JM (2004) Marked elevation of the chemokine CCL18/PARC in Gaucher disease: a novel surrogate marker for assessing therapeutic intervention. Blood 103:33-39 
Boot RG, Verhoek M, Langeveld M, Renkema GH, Hollak CE, Weening JJ, Donker-Koopman WE, Groener JE, Aerts JM (2006) CCL18: a urinary marker of Gaucher cell burden in Gaucher patients. J Inherit Metab Dis 29:564-571

Boot RG, Verhoek M, Donker-Koopman W, Strijland A, van Marle J, Overkleeft HS, Wennekes T, Aerts JM (2007) Identification of the non-lysosomal glucosylceramidase as beta-glucosidase 2. J Biol Chem 282:1305-1312

Boot RG, Hollak CE, Verhoek M, Alberts C, Jonkers RE, Aerts JM (2010) Plasma chitotriosidase and CCL18 as surrogate markers for granulomatous macrophages in sarcoidosis. Clin Chim Acta 411:31-36

Boutouyrie P, Laurent S, Laloux B, Lidove O, Grunfeld JP, Germain DP (2002) Arterial remodelling in Fabry disease. Acta Paediatr Suppl 91:62-66

Boven LA, Van Meurs M, Boot RG, Mehta A, Boon L, Aerts JM et al (2004) Gaucher cells demonstrate a distinct macrophage phenotype and resemble alternatively activated macrophages. Am J Clin Pathol 122:359-369

Boven LA, Van Meurs M, Van Zwam M, Wierenga-Wolf A, Hintzen RQ, Boot RG, Aerts JM, Amor S, Nieuwenhuis EE, Laman JD (2006) Myelin-laden macrophages are anti-inflammatory, consistent with foam cells in multiple sclerosis. Brain 129:517-526

Brady RO, Kanfer JN, Bradley RM, Shapiro D (1966) Demonstration of a deficiency of glucocerebroside-cleaving enzyme in Gaucher's disease. J Clin Invest 45:1112-1115

Brady RO, Gal AE, Bradley RM, Martensson E, Warshaw AL, Laster L (1967) Enzymatic defect in Fabry's disease. Ceramidetrihexosidase deficiency. N Engl J Med 276:1163-1167

Brinkman J, Wijburg FA, Hollak CE, Groener JE, Verhoek M, Scheij S, Aten J, Boot RG, Aerts JM (2005) Plasma chitotriosidase and CCL18: early biochemical surrogate markers in type B NiemannPick disease. J Inherit Metab Dis 28:13-20

Bussink AP, Van Eijk M, Renkema GH, Aerts JM, Boot RG (2006) The biology of the Gaucher cell: the cradle of human chitinases. Int Rev Cytol 252:71-128

Bussink AP, Speijer D, Aerts JM, Boot RG (2007) Evolution of mammalian chitinase(-like) members of family 18 glycosyl hydrolases. Genetics 177:959-970

Bussink AP, Verhoek M, Vreede J, Ghauharali-van der Vlugt K, Donker-Koopman WE, Sprenger RR, Hollak CE, Aerts JM, Boot RG (2009) Common G102S polymorphism in chitotriosidase differentially affects activity towards 4-methylumbelliferyl substrates. FEBS J 276:5678-5688

Cox T, Lachmann R, Hollak C, Aerts J, van Weely S, Hrebícek M, Platt F, Butters T, Dwek R, Moyses C, Gow I, Elstein D, Zimran A (2000) Novel oral treatment of Gaucher's disease with Nbutyldeoxynojirimycin (OGT 918) to decrease substrate biosynthesis. Lancet 355:1481-1485

Cox TM, Aerts JM, Andria G, Beck M, Belmatoug N, Bembi B, Chertkoff R, vom Dahl S, Elstein D, Erikson A, Giralt M, Heitner R, Hollak C, Hrebicek M, Lewis S, Mehta A, Pastores GM, Rolfs A, Miranda MC, Zimran A (2003) Advisory Council to the European Working Group on Gaucher Disease. The role of the iminosugar N-butyldeoxynojirimycin (miglustat) in the management of type I (non-neuronopathic) Gaucher disease: a position statement. J Inherit Metab Dis 26:513-526

Cox TM, Aerts JM, Belmatoug N, Cappellini MD, vom Dahl S, Goldblatt J, Grabowski GA, Hollak CE, Hwu P, Maas M, Martins AM, Mistry PK, Pastores GM, Tylki-Szymanska A, Yee J, Weinreb N (2008) Management of non-neuronopathic Gaucher disease with special reference to pregnancy, splenectomy, bisphosphonate therapy, use of biomarkers and bone disease monitoring. J Inherit Metab Dis 31:319-336

Cox-Brinkman J, van Breemen MJ, van Maldegem BT, Bour L, Donker WE, Hollak CE, Wijburg FA, Aerts JM (2008) Potential efficacy of enzyme replacement and substrate reduction therapy in three siblings with Gaucher disease type III. J Inherit Metab Dis 31:745-752

de Duve C, Pressman B, Gianetto R, Wattieux R, Pelsmans F (1955) Tissue fractionation studies. 6. Intracellular distribution patterns of enzymes in rat-liver tissue. Biochem J 60:604-617

de Fost M, Hollak CE, Groener JE, Aerts JM, Maas M, Poll LW, Wiersma MG, Häussinger D, Brett S, Brill N, vom Dahl S (2007) Superior effects of high-dose enzyme replacement therapy in type 1 Gaucher disease on bone marrow involvement and chitotriosidase levels: a 2-center retrospective analysis. Blood 108:830 835

de Fost M, Out TA, de Wilde FA, Tjin EP, Pals ST, van Oers MH, Boot RG, Aerts JF, Maas M, Vom Dahl S, Hollak CE (2008) Immunoglobulin and free light chain abnormalities in Gaucher disease type I: data from an adult cohort of 63 patients and review of the literature. Ann Hematol 87:439-449

de Fost M, Langeveld M, Franssen R, Hutten BA, Groener JE, de Groot E, Mannens MM, Bikker H, Aerts JM, Kastelein JJ, Hollak CE (2009) Low HDL cholesterol levels in type I Gaucher disease do not lead to an increased risk of cardiovascular disease. Atherosclerosis 204:267-272

Deegan PB, Moran MT, McFarlane I, Schofield JP, Boot RG, Aerts JM, Cox TM (2005) Clinical evaluation of chemokine and enzymatic biomarkers of Gaucher disease. Blood Cells Mol Dis 35:259-267

Dekker N, Voorn-Brouwer T, Verhoek M, Wennekes T, Narayan RS, Speijer D, Hollak CE, Overkleeft HS, Boot RG, Aerts JM (2010) The cytosolic beta-glucosidase GBA3 does not influence type 1 Gaucher disease manifestation. Blood Cells Mol Dis 46:19-26

Desnick RJ, Ioannou YA (2001) $\alpha$-Galactosidase a deficiency. Fabry disease. In: Scriver CR, Beaudet AL, Sly WS, Valle D (eds) The metabolic and molecular bases of inherited disease, 8th edn. McGraw-Hill, New York, pp 3733-3774

Dickson P, McEntee M, Vogler C, Le S, Levy B, Peinovich M, Hanson S, Passage M, Kakkis E (2007) Intrathecal enzyme replacement therapy: successful treatment of brain disease via the cerebrospinal fluid. Mol Genet Metab 91:61-68

Elstein D, Hollak C, Aerts JM, van Weely S, Maas M, Cox TM, Lachmann RH, Hrebicek M, Platt FM, Butters TD, Dwek RA, Zimran A (2004) Sustained therapeutic effects of oral miglustat (Zavesca, N-butyldeoxynojirimycin, OGT 918) in type I Gaucher disease. J Inherit Metab Dis 27:757-766

Elstein D, Dweck A, Attias D, Hadas-Halpern I, Zevin S, Altarescu G, Aerts JF, van Weely S, Zimran A (2007) Oral maintenance clinical trial with miglustat for type I Gaucher disease: switch from or combination with intravenous enzyme replacement. Blood 110:2296-2301

EMEA (2006) Report on the EMEA/CHMP Biomarkers Workshop, European Medicines Agency https://cbe0snz9r6ebbswtfa67p.sec. amc.nl/pdfs/human/biomarkers/42720905en.pdf

Eng CM, Guffon N, Wilcox WR, Germain DP, Lee P, Waldek S, Caplan L, Linthorst GE (2001) International Collaborative Fabry Disease Study Group. Safety and efficacy of recombinant human alpha-galactosidase A-replacement therapy in Fabry's disease. N Engl J Med 345:9-16

Erikson A, Forsberg H, Nilsson M, Astrom M, Mansson JE (2006) Ten years' experience of enzyme infusion therapy of Norrbottnian (type 3) Gaucher disease. Acta Paediatr 95:312-317

Fauler G, Rechberger GN, Devrnja D, Erwa W, Plecko B, Kotanko P, Breunig F, Paschke E (2005) Rapid determination of urinary globotriaosylceramide isoform profiles by electrospray ionization mass spectrometry using stearoyl-d35-globotriaosylceramide as internal standard. Rapid Commun Mass Spectrom 19:1499-1506

Froissart R, Guffon N, Vanier MT, Desnick RJ, Maire I (2003) Fabry disease: $\mathrm{D} 313 \mathrm{Y}$ is an alpha-galactosidase A sequence variant that 
causes pseudodeficient activity in plasma. Mol Genet Metab 80:307-314

Fuller M, Sharp PC, Rozaklis T, Whitfield PD, Blacklock D, Hopwood JJ, Meikle PJ (2005) Urinary lipid profiling for the identification of Fabry hemizygotes and heterozygotes. Clin Chem 51:688-694

Fusetti F, von Moeller H, Houston D, Rozeboom HJ, Dijkstra BW, Boot RG, Aerts JM, van Aalten DM (2002) Structure of human chitotriosidase. Implications for specific inhibitor design and function of mammalian chitinase-like lectins. J Biol Chem 277:25537-25544

Ghauharali-van der Vlugt K, Langeveld M, Poppema A et al (2007) Prominent increase in plasma ganglioside GM3 is associated with clinical manifestations of type I Gaucher disease. Clin Chim Acta 389:109-113

Goker-Alpan O, Lopez G, Vithayathil J, Davis J, Hallett M, Sidransky E (2008) The spectrum of parkinsonian manifestations associated with glucocerebrosidase mutations. Arch Neurol 65:1353-1357

Groener JE, Poorthuis BJ, Kuiper S, Helmond MT, Hollak CE, Aerts JM (2007) HPLC for simultaneous quantification of total ceramide, glucosylceramide, and ceramide trihexoside concentrations in plasma. Clin Chem 53:742-747

Groener JE, Poorthuis BJ, Kuiper S, Hollak CE, Aerts JM (2008) Plasma glucosylceramide and ceramide in type 1 Gaucher disease patients: correlations with disease severity and response to therapeutic intervention. Biochim Biophys Acta 1781:72-78

Guo Y, He W, Boer AM, Wevers RA, de Bruijn AM, Groener JE, Hollak CE, Aerts JM, Galjaard H, van Diggelen OP (1995) Elevated plasma chitotriosidase activity in various lysosomal storage disorders. J Inherit Metab Dis 18:717-722

Hein LK, Meikle PJ, Hopwood JJ, Fuller M (2007) Secondary sphingolipid accumulation in a macrophage model of Gaucher disease. Mol Genet Metab 92:336-345

Heitner R, Elstein D, Aerts J, Weely S, Zimran A (2002) Low-dose Nbutyldeoxynojirimycin (OGT 918) for type I Gaucher disease. Blood Cells Mol Dis 28(2):127-133

Hers HG (1963) $\alpha$-Glucosidase deficiency in generalized glycogen storage disease (Pompe's disease). Biochem J 86:11-16

Hollak CE, Van Weely S, Van Oers MH, Aerts JM (1994) Marked elevation of plasma chitotriosidase activity. A novel hallmark of Gaucher disease. J Clin Invest 93:1288-1292

Hollak CE, Aerts JM, Goudsmit R, Phoa SS, Ek M, van Weely S, von dem Borne AE, van Oers MH (1995) Individualised low-dose alglucerase therapy for type 1 Gaucher's disease. Lancet 345:1474-1478

Hollak CE, Levi M, Berends F, Aerts JM, van Oers MH (1997a) Coagulation abnormalities in type 1 Gaucher disease are due to low-grade activation and can be partly restored by enzyme supplementation therapy. Br J Haematol 96:470-476

Hollak CE, Evers L, Aerts JM, van Oers MH (1997b) Elevated levels of M-CSF, sCD14 and IL8 in type 1 Gaucher disease. Blood Cells Mol Dis 23:201-212

Hollak C, Maas M, Aerts J (2001) Clinically relevant therapeutic endpoints in type 1 Gaucher disease. J Inherit Metab Dis 24 (Suppl 2):97-105

Iyer A, van Eijk M, Silva E, Hatta M, Faber W, Aerts JM, Das PK (2009) Increased chitotriosidase activity in serum of leprosy patients: association with bacillary leprosy. Clin Immunol 131:501-509

Kalliokoski RJ, Kalliokoski KK, Penttinen M, Kantola I, Leino A, Viikari JS, Simell O, Nuutila P, Raitakari OT (2006) Structural and functional changes in peripheral vasculature of Fabry patients. J Inherit Metab Dis 29:660-666

Kaneski CR, Moore DF, Ries M, Zirzow GC, Schiffmann R (2006) Myeloperoxidase predicts risk of vasculopathic events in hemizgygous males with Fabry disease. Neurology 67:2045-2047
Labadaridis J, Dimitriou E, Costalos C, Aerts J, van Weely S, DonkerKoopman WE, Michelakakis H (1998) Serial chitotriosidase activity estimations in neonatal systemic candidiasis. Acta Paediatr 87:605

Langeveld M, Scheij S, Dubbelhuis P, Hollak CE, Sauerwein HP, Simons P, Aerts JM (2007) Very low serum adiponectin levels in patients with type 1 Gaucher disease without overt hyperglycemia. Metabolism 56:314-319

Langeveld M, de Fost M, Aerts JM, Sauerwein HP, Hollak CE (2008b) Overweight, insulin resistance and type II diabetes in type I Gaucher disease patients in relation to enzyme replacement therapy. Blood Cells Mol Dis 40:428-432

Langeveld M, Ghauharali KJ, Sauerwein HP, Ackermans MT, Groener JE, Hollak CE, Aerts JM, Serlie MJ (2008a) Type I Gaucher disease, a glycosphingolipid storage disorder, is associated with insulin resistance. J Clin Endocrinol Metab 93(3):845-851

Langeveld M, Aerts JM (2009) Glycosphingolipids and insulin resistance. Prog Lipid Res 48:196-205

Linthorst GE, Hollak CE, Donker-Koopman WE, Strijland A, Aerts JM (2004) Enzyme therapy for Fabry disease: neutralizing antibodies toward agalsidase alpha and beta. Kidney Int 66:1589-1595

Linthorst GE, Bouwman MG, Wijburg FA, Aerts JM, Poorthuis BJ, Hollak CE (2010) Screening for Fabry disease in high-risk populations: a systematic review. J Med Genet 47:217-222

Liou B, Grabowski GA (2009) Participation of asparagine 370 and glutamine 235 in the catalysis by acid beta-glucosidase: the enzyme deficient in Gaucher disease. Mol Genet Metab 97:65-74

Lonser RR, Walbridge S, Murray GJ, Aizenberg MR, Vortmeyer AO, Aerts JM, Brady RO, Oldfield EH (2005) Convection perfusion of glucocerebrosidase for neuronopathic Gaucher's disease. Ann Neurol 57:542-8.31

Lukina E, Watman N, Arreguin EA, Banikazemi M, Dragosky M, Iastrebner M, Rosenbaum H, Phillips M, Pastores GM, Rosenthal DI, Kaper M, Singh T, Puga AC, Bonate PL, Peterschmitt MJ (2010a) A phase 2 study of eliglustat tartrate (Genz-112638), an oral substrate reduction therapy for Gaucher disease type 1 . Blood 116:893-899

Lukina E, Watman N, Arreguin EA, Dragosky M, Iastrebner M, Rosenbaum H, Phillips M, Pastores GM, Kamath RS, Rosenthal DI, Kaper M, Singh T, Puga AC, Peterschmitt MJ (2010b) Improvement in hematological, visceral, and skeletal manifestations of Gaucher disease type 1 with oral eliglustat tartrate (Genz-112638) treatment: 2-year results of a phase 2 study. Blood 116:4095-4098

Maas M, Hollak CE, Akkerman EM, Aerts JM, Stoker J, Den Heeten GJ (2002) Quantification of skeletal involvement in adults with type I Gaucher's disease: fat fraction measured by Dixon quantitative chemical shift imaging as a valid parameter. AJR Am J Roentgenol 179:961-965

Maas M, van Kuijk C, Stoker J, Hollak CE, Akkerman EM, Aerts JF, den Heeten GJ (2003) Quantification of bone involvement in Gaucher disease: MR imaging bone marrow burden score as an alternative to Dixon quantitative chemical shift MR imaginginitial experience. Radiology 229:554-561

McEachern KA, Fung J, Komarnitsky S, Siegel CS, Chuang WL, Hutto E, Shayman JA, Grabowski GA, Aerts JM, Cheng SH, Copeland DP, Marshall J (2007) A specific and potent inhibitor of glucosylceramide synthase for substrate inhibition therapy of Gaucher disease. Mol Genet Metab 91:259-267

Meikle PJ, Hopwood JJ, Clague AE, Carey WF (1999) Prevalence of lysosomal storage disorders. JAMA 281:249-254

Meikle PJ, Whitfield PD, Rozaklis T, Blacklock D, Duplock S, Elstein D, Zimran A, Mengel E, Cannell P, Hopwood JJ, Fuller M (2008) Plasma lipids are altered in Gaucher disease: biochemical markers to evaluate therapeutic intervention. Blood Cells Mol Dis 40:420-427 
Michelakakis H, Spanou C, Kondyli A, Dimitriou E, Van Weely S, Hollak CE, Van Oers MH, Aerts JM (1996) Plasma tumor necrosis factor-a (TNF-a) levels in Gaucher disease. Biochim Biophys Acta 1317:219-222

Mills K, Vellodi A, Morris P, Cooper D, Morris M, Young E, Winchester B (2004) Monitoring the clinical and biochemical response to enzyme replacement therapy in three children with Fabry disease. Eur J Pediatr 163:595-603

Møller HJ, de Fost M, Aerts H, Hollak C, Moestrup SK (2004) Plasma level of the macrophage-derived soluble CD163 is increased and positively correlates with severity in Gaucher's disease. Eur J Haematol 72:135-139

Moore DF, Kaneski CR, Askari H, Schiffmann R (2007a) The cerebral vasculopathy of Fabry disease. J Neurol Sci 257(1-2):258-263

Moore DF, Krokhin OV, Beavis RC, Ries M, Robinson C, Goldin E, Brady RO, Wilkins JA, Schiffmann R (2007b) Proteomics of specific treatment-related alterations in Fabry disease: a strategy to identify biological abnormalities. Proc Natl Acad Sci USA 104:2873-2878

Moran MT, Schofield JP, Hayman AR, Shi GP, Young E, Cox TM (2000) Pathologic gene expression in Gaucher disease: upregulation of cysteine proteinases including osteoclastic cathepsin K. Blood 96:1969-1978

Ohashi T, Hong CM, Weiler S, Tomich JM, Aerts JM, Tager JM, Barranger JA (1991) Characterization of human glucocerebrosidase from different mutant alleles. J Biol Chem 266:3661-3667

Ohshima T, Murray GJ, Swaim WD, Longenecker G, Quirk JM, Cardarelli CO, Sugimoto Y, Pastan I, Gottesman MM, Brady RO, Kulkarni AB (1997) alpha-Galactosidase A deficient mice: a model of Fabry disease. Proc Natl Acad Sci USA 94:2540-2544

Pastores GM, Weinreb NJ, Aerts H, Andria G, Cox TM, Giralt M, Grabowski GA, Mistry PK, Tylki-Szymańska A (2004) Therapeutic goals in the treatment of Gaucher disease. Semin Hematol 41(4 Suppl 5):4-14

Phenix CP, Rempel BP, Colobong K, Doudet DJ, Adam MJ, Clarke LA, Withers SG (2010) Imaging of enzyme replacement therapy using PET. Proc Natl Acad Sci USA 107:10842-10847

Platt FM, Jeyakumar M, Andersson U, Priestman DA, Dwek RA, Butters TD, Cox TM, Lachmann RH, Hollak C, Aerts JM, Van Weely S, Hrebícek M, Moyses C, Gow I, Elstein D, Zimran A (2001) Inhibition of substrate synthesis as a strategy for glycolipid lysosomal storage disease therapy. J Inherit Metab Dis 24:275-290

Poll LW, Koch JA, Willers R, Aerts H, Scherer A, Häussinger D, Mödder U, vom Dahl S (2002) Correlation of bone marrow response with hematological, biochemical, and visceral responses to enzyme replacement therapy of nonneuronopathic (type 1) Gaucher disease in 30 adult patients. Blood Cells Mol Dis 28:209-220

Poorthuis BJ, Wevers RA, Kleijer WJ, Groener JE, de Jong JG, van Weely S, Niezen-Koning KE, van Diggelen OP (1999) The frequency of lysosomal storage diseases in The Netherlands. Hum Genet 105:151-156

Popli S, Leehey DJ, Molnar ZV, Nawab ZM, Ing TS (1990) Demonstration of Fabry's disease deposits in placenta. Am J Obstet Gynecol 162:464-465

Rao FV, Houston DR, Boot RG, Aerts JM, Sakuda S, van Aalten DM (2003) Crystal structures of allosamidin derivatives in complex with human macrophage chitinase. J Biol Chem 278:2011020116

Rao FV, Houston DR, Boot RG, Aerts JM, Hodkinson M, Adams DJ, Shiomi K, Omura S, van Aalten DM (2005) Specificity and affinity of natural product cyclopentapeptide inhibitors against A. fumigatus, human, and bacterial chitinases. Chem Biol 12:65-76

Reczek D, Schwake M, Schröder J, Hughes H, Blanz J, Jin X, Brondyk W, Van Patten S, Edmunds T, Saftig P (2007) LIMP-2 is a receptor for lysosomal mannose-6-phosphate-independent targeting of beta-glucocerebrosidase. Cell 131:770-783

Rempel BP, Withers SG (2008) Covalent inhibitors of glycosidases and their applications in biochemistry and biology. Glycobiology 18:570-586

Renkema GH, Boot RG, Muijsers AO, Donker-Koopman WE, Aerts JM (1995) Purification and characterization of human chitotriosidase, a novel member of the chitinase family of proteins. J Biol Chem 270:2198-2202

Renkema GH, Boot RG, Strijland A, Donker-Koopman WE, van den Berg M, Muijsers AO, Aerts JM (1997) Synthesis, sorting, and processing into distinct isoforms of human macrophage chitotriosidase. Eur J Biochem 244:279-285

Renkema GH, Boot RG, Au FL, Donker-Koopman WE, Strijland A, Muijsers AO, Hrebicek M, Aerts JM (1998) Chitotriosidase, a chitinase, and the $39-\mathrm{kDa}$ human cartilage glycoprotein, a chitinbinding lectin, are homologues of family 18 glycosyl hydrolases secreted by human macrophages. Eur J Biochem 251:504-509

Rijnboutt S, Aerts HM, Geuze HJ, Tager JM, Strous GJ (1991a) Mannose 6-phosphate-independent membrane association of cathepsin D, glucocerebrosidase, and sphingolipid-activating protein in HepG2 cells. J Biol Chem 266:4862-4868

Rijnboutt S, Kal AJ, Geuze HJ, Aerts H, Strous GJ (1991b) Mannose 6-phosphate-independent targeting of cathepsin D to lysosomes in HepG2 cells. J Biol Chem 266:23586-23592

Rombach SM, Dekker N, Bouwman MG, Linthorst GE, Zwinderman $\mathrm{AH}$, Wijburg FA, Kuiper S, van den Bergh Weerman MA, Groener JE, Poorthuis BJ, Hollak CE, Aerts JM (2010a) Plasma globotriaosylsphingosine: diagnostic value and relation to clinical manifestations of Fabry disease. Biochim Biophys Acta 1802:741-748

Rombach SM, Twickler TB, Aerts JM, Linthorst GE, Wijburg FA, Hollak CE (2010b) Vasculopathy in patients with Fabry disease: current controversies and research directions. Mol Genet Metab 99:99-108

Sanchez-Niño MD, Sanz AB, Carrasco S, Saleem MA, Mathieson PW, Valdivielso JM, Ruiz-Ortega M, Egido J, Ortiz A (2010) Globotriaosylsphingosine actions on human glomerular podocytes: implications for Fabry nephropathy. Nephrol Dial Transplant [Epub ahead of print]

Schiffmann R, Heyes MP, Aerts JM, Dambrosia JM, Patterson MC, DeGraba T, Parker CC, Zirzow GC, Oliver K, Tedeschi G, Brady RO, Barton NW (1997) Prospective study of neurological responses to treatment with macrophage-targeted glucocerebrosidase in patients with type 3 Gaucher's disease. Ann Neurol 42:613-621

Schiffmann R, Kopp JB, Austin HA 3rd, Sabnis S, Moore DF, Weibel T, Balow JE, Brady RO (2001) Enzyme replacement therapy in Fabry disease: a randomized controlled trial. JAMA 285:27432749

Schiffmann R (2009) Fabry disease. Pharmacol Ther 122:65-77

Schoonhoven A, Rudensky B, Elstein D, Zimran A, Hollak CE, Groener JE, Aerts JM (2007) Monitoring of Gaucher patients with a novel chitotriosidase assay. Clin Chim Acta 381:136-139

Shah JS, Hughes DA, Tayebjee MH, MacFadyen RJ, Mehta AB, Elliott PM (2007) Extracellular matrix turnover and disease severity in Anderson-Fabry disease. J Inherit Metab Dis 30:88-95

Sidransky E (2004) Gaucher disease: complexity in a "simple" disorder. Mol Genet Metab 83:6-15

Smid BE, Aerts JM, Boot RG, Linthorst GE, Hollak CE (2010) Pharmacological small molecules for the treatment of lysosomal storage disorders. Expert Opin Investig Drugs 19:1367-1379

Tan MA, Dean CJ, Hopwood JJ, Meikle PJ (2008) Diagnosis of metachromatic leukodystrophy by immune quantification of arylsulphatase A protein and activity in dried blood spots. Clin Chem 54:1925-1927 
Togawa T, Kawashima I, Kodama T, Tsukimura T, Suzuki T, Fukushige T, Kanekura T, Sakuraba H (2010a) Tissue and plasma globotriaosylsphingosine could be a biomarker for assessing enzyme replacement therapy for Fabry disease. Biochem Biophys Res Commun 399:716-720

Togawa T, Kodama T, Suzuki T, Sugawara K, Tsukimura T, Ohashi T, Ishige N, Suzuki K, Kitagawa T, Sakuraba H (2010b) Plasma globotriaosylsphingosine as a biomarker of Fabry disease. Mol Genet Metab 100:257-261

Urayama A, Grubb JH, Banks WA, Sly WS (2007) Epinephrine enhances lysosomal enzyme delivery across the blood brain barrier by up-regulation of the mannose 6-phosphate receptor. Proc Natl Acad Sci USA 104:12873-12878

van Breemen MJ, Bleijlevens B, de Koster CG, Aerts JM (2006) Limitations in quantitation of the biomarker CCL18 in Gaucher disease blood samples by surface-enhanced laser desorption/ ionization time-of-flight mass spectrometry. Biochim Biophys Acta 1764:1626-1632

van Breemen MJ, de Fost M, Voerman JS, Laman JD, Boot RG, Maas M, Hollak CE, Aerts JM, Rezaee F (2007) Increased plasma macrophage inflammatory protein (MIP)-1alpha and MIP-1beta levels in type 1 Gaucher disease. Biochim Biophys Acta 1772:788-796

van Breemen MJ, Aerts JM, Sprenger RR, Speijer D (2008) Potential artefacts in proteome analysis of plasma of Gaucher patients due to protease abnormalities. Clin Chim Acta 396:26-32

van Breemen MJ, de Fost M, Maas M, Wiersma MG, Hollak CE, Poll LW, Vom Dahl S, Boot RG, Aerts JM (2009) Different dosedependent correction of MIP-1beta and chitotriosidase during initial enzyme replacement therapy. J Inherit Metab Dis 32:274279

van Breemen MJ, Rombach SM, Dekker N, Poorthuis BJ, Linthorst GE, Zwinderman AH, Breunig F, Wanner C, Aerts JM, Hollak CE (2011) Reduction of elevated plasma globotriaosylsphingosine in patients with classic Fabry disease following enzyme replacement therapy. Biochim Biophys Acta 1812:70-76

van Eijk M, van Roomen CP, Renkema GH, Bussink AP, Andrews L, Blommaart EF, Sugar A, Verhoeven AJ, Boot RG, Aerts JM (2005) Characterization of human phagocyte-derived chitotriosidase, a component of innate immunity. Int Immunol 17:15051512

van Es HH, Renkema H, Aerts H, Schurr E (1994) Enhanced lysosomal acidification leads to increased chloroquine accumulation in CHO cells expressing the pfmdr1 gene. Mol Biochem Parasitol 68:209-219

Van Weely S, Van Leeuwen MB, Jansen ID, De Bruijn MA, BrouwerKelder EM, Schram AW, Sa Miranda MC, Barranger JA, Petersen EM, Goldblatt J et al (1991) Clinical phenotype of Gaucher disease in relation to properties of mutant glucocerebrosidase in cultured fibroblasts. Biochim Biophys Acta 1096:301-311

van Weely S, Brandsma M, Strijland A, Tager JM, Aerts JM (1993a) Demonstration of the existence of a second, non-lysosomal glucocerebrosidase that is not deficient in Gaucher disease. Biochim Biophys Acta 1181:55-62

van Weely S, van den Berg M, Barranger JA, Sa Miranda MC, Tager JM, Aerts JM (1993b) Role of $\mathrm{pH}$ in determining the cell-typespecific residual activity of glucocerebrosidase in type 1 Gaucher disease. J Clin Invest 91:1167-1175
Vedder AC, Cox-Brinkman J, Hollak CE, Linthorst GE, Groener JE, Helmond MT, Scheij S, Aerts JM (2006a) Plasma chitotriosidase in male Fabry patients: a marker for monitoring lipid-laden macrophages and their correction by enzyme replacement therapy. Mol Genet Metab 89:239-244

Vedder AC, Strijland A, vd Bergh Weerman MA, Florquin S, Aerts JM, Hollak CE (2006b) Manifestations of Fabry disease in placental tissue. J Inherit Metab Dis 29:106-111

Vedder AC, Linthorst GE, Houge G, Groener JE, Ormel EE, Bouma BJ, Aerts JM, Hirth A, Hollak CE (2007a) Treatment of Fabry disease: outcome of a comparative trial with agalsidase alfa or beta at a dose of $0.2 \mathrm{mg} / \mathrm{kg}$. PLoS ONE 2:e598

Vedder AC, Gerdes VE, Poorthuis BJ, Helmond M, Trip MD, Aerts JM, Hollak CE (2007b) Failure to detect Fabry patients in a cohort of prematurely atherosclerotic males. J Inherit Metab Dis 30:988

Vedder AC, Linthorst GE, van Breemen MJ, Groener JE, Bemelman FJ, Strijland A, Mannens MM, Aerts JM, Hollak CE (2007c) The Dutch Fabry cohort: diversity of clinical manifestations and Gb3 levels. J Inherit Metab Dis 30:68-78

Vedder AC, Breunig F, Donker-Koopman WE, Mills K, Young E, Winchester B, Ten Berge IJ, Groener JE, Aerts JM, Wanner C, Hollak CE (2008) Treatment of Fabry disease with different dosing regimens of agalsidase: effects on antibody formation and GL-3. Mol Genet Metab 94:319-325

Vedder AC, Biró E, Aerts JM, Nieuwland R, Sturk G, Hollak CE (2009) Plasma markers of coagulation and endothelial activation in Fabry disease: impact of renal impairment. Nephrol Dial Transplant 24:3074-3081

Vissers JP, Langridge JI, Aerts JM (2007) Analysis and Quantification of Diagnostic Serum Markers and Protein Signatures for Gaucher Disease. Mol Cell Proteomics 6:755-766

vom Dahl S, Harzer K, Rolfs A, Albrecht B, Niederau C, Vogt C, van Weely S, Aerts J, Müller G, Häussinger D (1999) Hepatosplenomegalic lipidosis: what unless Gaucher? Adult cholesteryl ester storage disease (CESD) with anemia, mesenteric lipodystrophy, increased plasma chitotriosidase activity and a homozygous lysosomal acid lipase -1 exon 8 splice junction mutation. J Hepatol 31:741-746

Wennekes T, van den Berg RJ, Boot RG, van der Marel GA, Overkleeft HS, Aerts JM (2009) Glycosphingolipids-nature, function, and pharmacological modulation. Angew Chem Int Ed Engl 48:8848-8869

Whitfield PD, Calvin J, Hogg S, O'Driscoll E, Halsall D, Burling K, Maguire G, Wright N, Cox TM, Meikle PJ, Deegan PB (2005) Monitoring enzyme replacement therapy in Fabry disease-role of urine globotriaosylceramide. J Inherit Metab Dis 28(1):21-33

Witte MD, Kallemeijn WW, Aten J, Li KY, Strijland A, DonkerKoopman WE, van den Nieuwendijk AM, Bleijlevens B, Kramer G, Florea BI, Hooibrink B, Hollak CE, Ottenhoff R, Boot RG, van der Marel GA, Overkleeft HS, Aerts JM (2010) Ultrasensitive in situ visualization of active glucocerebrosidase molecules. Nat Chem Biol 6(12):907-913

Yildiz Y, Matern H, Thompson B, Allegood JC, Warren RL, Ramirez DM, Hammer RE, Hamra FK, Matern S, Russell DW (2006) Mutation of beta-glucosidase 2 causes glycolipid storage disease and impaired male fertility. J Clin Invest 116:2985-2994

Young E, Mills K, Morris P, Vellodi A, Lee P, Waldek S, Winchester B (2005) Is globotriaosylceramide a useful biomarker in Fabry disease? Acta Paediatr Suppl 94(447):51-54 